\title{
Effect of Seedcoat Manipulation on the Germination of Stenospermocarpic Grape Embryos Cultured in Ovulo
}

\author{
Gina E. Fernandez, John R. Clark ${ }^{2}$, and J.N. Moore ${ }^{3}$ \\ Department of Horticulture and Forestry, University of Arkansas, \\ Fayetteville, AR 72701
}

Additional index words. Vitis spp., fruit breeding

The development of in-ovulo culture techniques has allowed grape breeders to perform seedless $\times$ seedless hybridizations using stenospermocarpic female parents (Emershad and Ramming, 1984). This technique requires culturing intact ovules in vitro for several months and then excising the embryos from the ovule. The excision is carried out in aseptic conditions and is quite tedious. Many embryos are lost from wounds or other mishaps.

Embryos can grow directly out of ruptured ovules (Gray et al., 1987) and from intact ovules (Spiegel-Roy et al., 1985). Methods that would reproduce the success of the techniques but eliminate complete embryo excision would streamline embryo rescue. We studied the effect of seedcoat manipulation on germination of stenospermocarpic grape embryos cultured in ovulo.

Ovules from five controlled cross pollinations, including as parents 'Saturn' and 'Venus' and breeding selections A-1905, A1728, and A-1692 (Table 1) were cultured 8 weeks after bloom on a modified Murashige and Skoog (1962) medium as described in Gray et al. (1987). One of three culture regimes was administered to a group of ovules: 1) The procedure of Gray et al. (1987) involving culture of intact ovules on a solid medium for several weeks, followed by ex-

Received for publication 3 Dec. 1990. Published with approval of the Director, Arkansas Agricultural Experiment Station. The cost of publishing this paper was defrayed in part by the payment of page charges. Under postal regulations, this paper therefore must be hereby marked advertisement solely to indicate this fact.

${ }^{1}$ Research Specialist, Fruit Substation. Present address: Dept. of Fruit and Vegetable Science, Cornell Univ., Ithaca, NY 14853.

${ }^{2}$ Resident Director, Fruit Substation, Clarksville, AR 72830

Distinguished Professor. cision of the embryo. The embryo was then subcultured to fresh medium. 2) Ovules were initially excised from the fruit and sliced horizontally at the chalazal end but perpendicular to the embryo. About one-fourth of the seedcoat and adjacent endosperm was removed. The portion of the ovule containing the embryo was then placed with the cut surface in direct contact with the medium. After 3 weeks, ovules were repositioned and the cut end was no longer in direct contact with the medium. 3) We cultured intact ovules in vitro with no embryo excision or manipulation of the seedcoat during any part of the experiment.

For germination to occur, embryos must be removed from the remainder of the seed (Table 1). In all treatments, the highest percentage of both germinated embryos and established plants was obtained when the embryos were removed from the seed coat and endosperm. Removing part of the seed- coat allowed some embryos to germinate; however, no established plants were obtained from this treatment. No embryos grew from intact ovules.

All female parents used in this study had large seed traces and were therefore considered to have a greater probability of producing viable embryos. 'Venus' and 'Saturn' had a higher percentage germination when embryos were excised than did other genotypes we used. Goldy and Amborn (1987) found that some stenospermocarpic genotypes are more successfully cultured in ovulo than others. Until alternative strategies can be developed involving culture manipulation of ovules, embryo excision continues to be the best method for obtaining plants from stenospermocarpic genotypes.

\section{Literature Cited}

Emershad, R.L. and D.W. Ramming. 1984. In ovulo embryo culture of Vitis vinifera L. c.v. 'Thompson Seedless'. Amer. J. Bot. 71:873877.

Goldy, R.G. and U. Amborn. 1987. In vitro culturability of ovules from 10 seedless grape clones. HortScience 22:952.

Gray, D.J., L.C. Fisher, and J.A. Mortensen. 1987. Comparison of methodologies for in ovulo embryo rescue of seedless grapes. HortScience 22:1334-1335.

Murashige, T. and F. Skoog. 1962. A revised medium for rapid growth and bioassays with tobacco tissue cultures. Physiol. Plant. 15:473497.

Spiegel-Roy, P., N. Sahar, J. Baron, and U. Lavi. 1985. In vitro culture and plant formation from grape cultivars with abortive ovules and seeds. J. Amer. Soc. Hort. Sci. 110:109-112.

Table 1. Effect of seedcoat manipulation on embryo germination and plants recovered from seedless $\times$ seedless crosses.

\begin{tabular}{llccc}
\hline \hline Cross & Treatment & $\begin{array}{c}\text { No. ovules } \\
\text { cultured }\end{array}$ & $\begin{array}{c}\text { Germination } \\
(\%)\end{array}$ & $\begin{array}{c}\text { Established } \\
\text { plants } \\
(\%)\end{array}$ \\
\hline Saturn x A-1905 & 1. Excise & 60 & 37.0 & 15.0 \\
& 2. Cut & 20 & 0.0 & 0.0 \\
A. Control & 19 & 0.0 & 0.0 \\
& 3. Excise & 18 & 17.0 & 0.0 \\
A-1692 $\times$ A-1728 & 2. Cut & 20 & 15.0 & 0.0 \\
& 3. Control & 14 & 0.0 & 0.0 \\
& 1. Excise & 20 & 10.0 & 5.0 \\
Saturn $\times$ Venus & 2. Cut & 20 & 0.0 & 0.0 \\
& 3. Control & 20 & 0.0 & 0.0 \\
& 1. Excise & 69 & 22.0 & 3.0 \\
Venus $\times$ Saturn & 2. Cut & 24 & 13.0 & 0.0 \\
& 3. Control & 0 & 0.0 & 0.0 \\
& 1. Excise & 39 & 67.0 & 33.0 \\
& 2. Cut & 55 & 2.0 & 0.0 \\
& 3. Control & 20 & 0.0 & 0.0 \\
\hline
\end{tabular}

